Yüzüncü Y1l Üniversitesi
Tarim Bilimleri Dergisi

Araştırma Makalesi (Research Article)

Investigation of Effect of Ultrasound Pretreatment on Drying and Rehydration Characteristics and Microstructure of Apple Slices

\author{
Senem TÜFEKÇi் ${ }^{1}$, Sami Gökhan ÖZKAL ${ }^{2 *}$ \\ ${ }^{1}$ Department of Food Processing, Vocational School of Acıpayam, Pamukkale University, 20800, Denizli, \\ Turkey \\ ${ }^{2}$ Department of Food Engineering, Faculty of Engineering, Pamukkale University, 20160, Denizli, Turkey
}

${ }^{1}$ https://orcid.org/0000-0002-4613-2418 ${ }^{2}$ https://orcid.org/0000-0001-5040-9814

*Corresponding author e-mail: sgozkal@pau.edu.tr

\section{Article Info}

Received: 04.03.2020

Accepted: 22.12.2020

Online Published 31.12.2020

DOI: $10.29133 /$ yyutbd.698826

Keywords

Apple,

Drying,

Mathematical modeling,

Microstructure,

Rehydration,

Ultrasound.

\begin{abstract}
In this study, the effects of ultrasound pretreatment on hot air drying and rehydration characteristics and microstructure changes of apple slices were examined. Slices of apple cv. Granny Smith having $5 \mathrm{~mm}$ thickness were used as the material. Pretreatments with ultrasound application were done by an ultrasonic generator with $20 \mathrm{kHz}$ frequency. Effect of pretreatment time (10, 20, $30 \mathrm{~min}$ ) and amplitude (55 and $100 \%$ ) were evaluated. Drying experiments were performed in a cabinet drier at $60^{\circ} \mathrm{C}$ with $0.3 \mathrm{~m} \cdot \mathrm{s}^{-1}$ constant air velocity. Application of ultrasound pretreatment decreased the drying time of apple slices in some conditions. Amongst the five thin layer drying models tested, the Page and Modified Page models found to be the best fitting models for the expression of the drying of apple slices. Microstructural changes caused by ultrasound pretreatment enhanced the rehydration ability of dried apples. As the pretreatment time and ultrasound amplitude increased, the rehydration ratio had an increasing trend. Peleg model represented the rehydration kinetics of the samples successfully. Changes in the microstructure of the apple samples caused by the ultrasound pretreatment were clearly observed with scanning electron microscopy images. Structural changes, caused by ultrasound pretreatment in apple tissues, resulted in low shrinkage values.
\end{abstract}

\title{
Ultrases Ön İșleminin Elma Dilimlerinin Kurutma ve Rehidrasyon Karakteristikleri ile Mikroyapısına Etkisinin Araştırılması
}

\section{Makale Bilgileri}

Geliș: 04.03.2020

Kabul: 22.12.2020

Online Yayınlanma 31.12.2020

DOI: $10.29133 /$ yyutbd.698826

\section{Anahtar kelimeler}

Elma,

Kurutma,

Matematiksel modelleme,

Rehidrasyon,

Mikroyapı,

Ultrases.
Öz: Bu çalışmada, ultrasonik ön işlem uygulamasının elma dilimlerinin sıcak hava ile kurutulması, rehidrasyon özellikleri ve mikro yapısında meydana gelen değişikler üzerine etkisi araştırılmıştır. Materyal olarak $5 \mathrm{~mm}$ kalınlığında Granny Smith elma çeşidinin dilimleri kullanılmıştır. Ultrases ön işlemi $20 \mathrm{kHz}$ frekanslı ultrases üreticisi ile yapılmıştır. Ultrases ön işleminin etkisi seçilen süre (10, 20, 30 dakika) ve genlik (\% 55 ve \% 100) değerlerinde incelenmiştir. Kurutma deneyleri kabin kurutucuda $60{ }^{\circ} \mathrm{C}^{\prime}$ de ve $0.3 \mathrm{~m} . \mathrm{s}^{-1}$ sabit hava hızında gerçekleştirilmiştir. Ultrases ön işlemi, bazı koşullarda elma dilimlerinin kuruma süresini kısaltmıştır. Denenen beş ince tabaka kurutma modeli arasından Page ve Modifiye Page modelleri elma dilimlerinin kurutulmasını ifade eden en uygun modeller olarak bulunmuştur. Ultrases ön işleminin neden olduğu mikroyapısal değişiklikler, kurutulmuş elmaların rehidrasyon kabiliyetini arttırmıştır. Ön işlem süresi ve ultrases genliği arttıkça rehidrasyon oranı artış eğiliminde olmuştur. Peleg modeli 
örneklerin rehidrasyon kinetiğini başarılı biçimde temsil etmiştir. Ultrases ön işlemi ile elma örneklerinin mikroyapısında meydana gelen değişimler taramalı elektron mikroskobu görüntüleri ile açık bir şekilde gözlemlenmiştir. Ultrases ön işlemi ile elma dokusunda meydana gelen yapısal değişiklikler düşük büzüşme oranı değerleri olarak sonuçlanmıştır.

\section{Introduction}

Apple is used as a raw material in many food formulations and cultivated in almost every part of the World because of its flavor and rich nutrients (Andres et al., 2004; Aras and Eşitken, 2019). Consumption of apple can be in fresh or processed forms such as juices, jams, marmalades, purees and dried products (Sacilik and Elicin, 2006). In recent years demand for the dried snack fruit products increasing due to their ease of use and healthy effects (Turgut and Topuz, 2020). Developing new apple preservation techniques is important.

Hot air drying is widely used for preservation of food and agricultural products. However, this method has several disadvantages like undesirable flavor and color, nutrient loss due to long drying time (Contreras et al., 2008). The use of ultrasound as a new technology may defeat some of the disadvantages of hot air drying (Garcia-Perez et al., 2007). Utilization of ultrasound technology has attracted large interest due to its promising effects in food processing (Knorr et al., 2004). Pre or simultaneous application of ultrasound energy in convective drying has increased the drying rate without a notable loss of quality in the product. Ultrasound has also increased the diffusion of water by reducing the internal resistance caused by the inner boundary layer (Rastogi, 2011).

In literature, the impact of ultrasound energy on drying behavior and characteristics of apples has been investigated widely with different drying methods such as low temperature air drying (Sabarez et al., 2018), convective air drying (Rojas et al.,2020; Banaszak and Pawłowski, 2018), atmospheric freeze drying (Moreno et al., 2017), vacuum freeze drying (Zhang et al., 2020; Ren and Bai, 2018), osmotic dehydration (Fernandes et al., 2019; Mierzwa and Kowalski, 2016) and microwave drying (Wiktor and Witrowa-Rajchert, 2020; Lv et al., 2019).

The objective of this study was to determine the influence of ultrasonic pretreatment on hot air drying and rehydration characteristics, shrinkage, rehydration ratio, water holding capacity and microstructural changes of Granny Smith apple slices. This study differs from the previous studies reported in literature with the application method of ultrasound energy and modeling the experimental drying data by using thin layer mathematical models.

\section{Materials and Methods}

Fresh apples ( $c v$. Granny Smith) were purchased from a bazaar in Denizli. Samples were stored in a refrigerator at $+4^{\circ} \mathrm{C}$ in polyethylene freezer bags until being dried. Moisture content was determined by gravimetric method in a hot air oven at $105^{\circ} \mathrm{C}$.

\subsection{Ultrasound pretreatment}

Apples were washed, peeled and cut into cylindrical slices of constant thickness ( $5 \mathrm{~mm}$ ) by an electronic fresh vegetable cutter (Moulinex Fresh Express, France). Then the apple slices were dipped in distilled water at $25^{\circ} \mathrm{C}$ for sonication. Solid/liquid ratio used was $1: 4(\mathrm{w} / \mathrm{w})$. The sonication processes were done by using an ultrasonic generator (Bandelin Sonopuls, Model HD 2200) working at $200 \mathrm{~W}$ power and $20 \mathrm{kHz}$ frequency having a $13 \mathrm{~mm}$ diameter titanium probe (TT 13). Time and amplitude values of ultrasound pretreatment were chosen as 10, 20 and $30 \mathrm{~min}$, and 55 and $100 \%$, respectively (Tüfekçi and Özkal, 2017).

Variations in temperature during ultrasonic pretreatment depending on conditions applied were determined by measuring the temperature of the distilled water before and after the pretreatment. Mass changes of the samples were determined by weighing the samples after removing superficial water at the end of pretreatments. 


\subsection{Drying experiments}

Drying of apple samples were performed in a tray dryer (Yucebas Machine, İzmir, Turkey) (Demiray and Tülek, 2014). To achieve steady state conditions, the dryer was powered on $1 \mathrm{~h}$ before each drying experiment. The apple slices were weighed and placed uniformly as a single layer on the trays. The trays were inserted into the drier which were set to a constant air temperature $\left(60^{\circ} \mathrm{C}\right)$ and velocity $\left(0.3 \mathrm{~m} \cdot \mathrm{s}^{-1}\right)$.

The samples were weighed at every 5 min during the first $30 \mathrm{~min}$, then every $30 \mathrm{~min}$ until constant weight conditions were observed. All drying experiments were performed in duplicate and average values of each condition were reported.

\subsection{Shrinkage}

For the determination of shrinkage values, bulk volume of samples was measured by a gas pycnometer (Micromeritics, Model AccuPyc II 1340) and the shrinkage values were calculated from the volume reduction of apple slices as percent shrinkage (S) (Equation 1) (Deng and Zhao, 2008);

$$
S=\left[\left(V_{0}-V_{S}\right) / V_{0}\right] \times 100
$$

Where $V_{0}$ and $V_{s}$ are volumes of the initial (fresh) and dried sample, respectively. For each measurement, 5 apple slices were selected and the measurements were performed in duplicate and the average value of percent shrinkage of the samples at each condition were reported.

\subsection{Rehydration experiments}

The rehydration experiments of dried apple samples were done at a constant temperature of $60^{\circ} \mathrm{C}$. Dried apple samples were immersed into distilled water at a solid/liquid ratio of 1:50 (w/w). Samples were weighed after each 5 min of immersion during the first 30 min then every 30 min until a constant weight was attained. The superficial water was removed by draining samples over a mesh for $30 \mathrm{~s}$ prior to each measurement.

Rehydration ratio $(R R)$ was estimated from the Equation 2;

$$
R R=w_{r t} / w_{r 0}
$$

Where $w_{r t}$ is mass of the rehydrated sample and $w_{r 0}$ is mass of the dry sample.

To obtain the water holding capacity (WHC), rehydrated samples were centrifuged at $4000 \mathrm{rpm}$ for $10 \mathrm{~min}$ at $5^{\circ} \mathrm{C}$ in tubes having a mesh in the center and water removed from samples were weighed. The $W H C$ values were estimated from the measured masses of the samples by using the Equation 3 (Vega-Gálvez et al., 2009);

$$
W H C=[(M r . X r-M s) /(M r . X r)] .100
$$

Where $M r$ is the mass of the sample after rehydration, $X r$ is the moisture content wet basis and $M s$ is the mass of the removed liquid from rehydrated sample after centrifugation.

\subsection{Drying kinetics}

The equations given below (Equation 4 and 5) were used for estimation of the moisture ratio $(M R)$ and drying rate $(D R)$ of the apple samples:

$$
M R=\frac{M_{t}-M_{e}}{M_{0}-M_{e}}
$$




$$
D R=\frac{M_{t+d t}-M_{t}}{d t}
$$

Where, $M_{0}$ is the initial moisture content, $M_{\mathrm{e}}$ is the equilibrium moisture content, $M_{t}$ is the moisture content at any time $t$, and $M_{t^{+}+\mathrm{t} t}$ is the moisture content at $t+\mathrm{d} t$ (g water.g dry matter ${ }^{-1}$ ) and $t$ is the drying time (min) (Sacilik and Elicin, 2006).

Mathematical modeling is necessary for food technology to understand the phenomenia of drying and rehydration process (Cruz et al., 2015). Five different thin layer models given in Table 1 were used for estimation of drying kinetics of experimental data of the apple samples.

Table 1. Thin layer models used (Demiray and Tülek, 2014)

\begin{tabular}{cll}
\hline Model no & Model name & Model equation \\
\hline 1 & Lewis & $M R=\exp (-\mathrm{k} t)$ \\
2 & Henderson and Pabis & $M R=\mathrm{a} \exp (-\mathrm{k} t)$ \\
3 & Page & $M R=\exp \left(-\mathrm{k} t^{\mathrm{n}}\right)$ \\
4 & Modified Page & $M R=\exp \left(-(\mathrm{k} t)^{\mathrm{n}}\right)$ \\
5 & Logarithmic & $M R=\mathrm{a} \exp (-\mathrm{k} t)+\mathrm{c}$ \\
\hline
\end{tabular}

\subsection{Rehydration kinetics} experiments;

Peleg model (Equation 6) was used for modeling of the data obtained from the rehydration

$$
M=M_{0}+t /\left(k_{1}+k_{2} t\right)
$$

In this equation $M_{0}$ is the initial moisture content, $M$ is the moisture content at time $t, k_{1}$ is the Peleg rate constant and $k_{2}$ is the Peleg capacity constant (Ricce et al., 2016).

\subsection{Statistical analysis}

To describe the most suitable model representing the drying and rehydration curves of the apple samples, the $\mathrm{R}^{2}$, reduced chi-square $\left(\chi^{2}\right)$ and root mean square error (RMSE) were used as the statistical parameters.

$$
\begin{aligned}
\chi^{2} & =\frac{\sum_{i=1}^{N}\left(M R_{\text {exp }, i}-M R_{\text {pre }, i}\right)^{2}}{N-n} \\
\text { RMSE } & =\left[\frac{1}{N} \sum_{i=1}^{N}\left(M R_{\text {pre }, i}-M R_{\text {exp }, i}\right)^{2}\right]^{1 / 2}
\end{aligned}
$$

The model which has the greatest $\mathrm{R}^{2}$, and least $\chi^{2}$ and RMSE was selected as the best representing model of the drying kinetics of the apples.

\subsection{Microstructure}

To investigate the impact of ultrasonic pretreatment on the microstructure of the apple slices, scanning electron microscopy (SEM) micrographs of the control (untreated samples) and the 20 min sonicated samples with 55 and $100 \%$ amplitudes dried at $60^{\circ} \mathrm{C}$ were obtained by using FEI Quanta 250 FEG instrument. 


\section{Results}

\subsection{Temperature and mass change during ultrasound pretreatment}

Temperature changes of the immersing water used in ultrasonic pretreatment and mass changes of the apple samples after ultrasound pretreatment were presented in Table 2.

Before ultrasound pretreatment, the temperature of the immersing water was $25^{\circ} \mathrm{C}$. It increased up to $56.50^{\circ} \mathrm{C}$ during ultrasound pretreatment. Additionally, mass loss in the samples increased with increasing pretreatment time and ultrasound amplitude. As a result, mass of the apple slices decreased.

Table 2. Changes occurred during ultrasound pretreatments

\begin{tabular}{cccc}
\hline \multicolumn{2}{c}{ Pretreatment conditions } & Change in temperature $\left({ }^{\circ} \mathrm{C}\right)^{*}$ & Change in mass $(\%)^{*}$ \\
\hline Amplitude (\%) & Time (min) & $29.75 \pm 0.50$ & $-0.96 \pm 0.07$ \\
& 10 & $50.00 \pm 0.83$ & $-3.10 \pm 0.14$ \\
& 20 & $56.50 \pm 1.29$ & $-3.35 \pm 0.44$ \\
55 & 30 & $29.00 \pm 0.82$ & $-0.80 \pm 0.05$ \\
\hline
\end{tabular}

"Values are given as "mean \pm standard deviation" $n=4$

\subsection{Drying characteristics}

Sample codes indicating the drying temperature and pretreatment conditions for apple samples were listed in Table 3 and the same codes were used throughout the study. Total drying times of apple samples at $60{ }^{\circ} \mathrm{C}$ to the final moisture content of $0.1 \mathrm{~g}$ water.g dry matter ${ }^{-1}$ were also reported in Table 3.

Table 3. Times needed to reach final moisture content for coded samples.

\begin{tabular}{ccccc}
\hline $\begin{array}{c}\text { Drying } \\
\text { temperature } \\
\left({ }^{\circ} \mathrm{C}\right)\end{array}$ & $\begin{array}{c}\text { Pmplitude } \\
(\%)\end{array}$ & $\begin{array}{c}\text { Time } \\
(\text { min })\end{array}$ & Sample code & $\begin{array}{c}\text { Time neded to reach } \\
\text { final moisture content } \\
(\text { min })\end{array}$ \\
\cline { 2 - 4 } & - & - & $60{ }^{\circ} \mathrm{C}$ control & 143 \\
60 & 100 & 20 & $60^{\circ} \mathrm{C}-100 \%-10 \mathrm{~min}$ & 210 \\
& & $60{ }^{\circ} \mathrm{C}-100 \%-20 \mathrm{~min}$ & 117 \\
& 55 & 20 & $60^{\circ} \mathrm{C}-100 \%-30 \mathrm{~min}$ & 113 \\
\hline
\end{tabular}

Influence of ultrasound pretreatment on drying kinetics of apple slices are given in Figure 1 and 2. Figure 1 shows drying rate versus moisture content curves and Figure 2 shows the changes in $M R$ values with the drying time. 


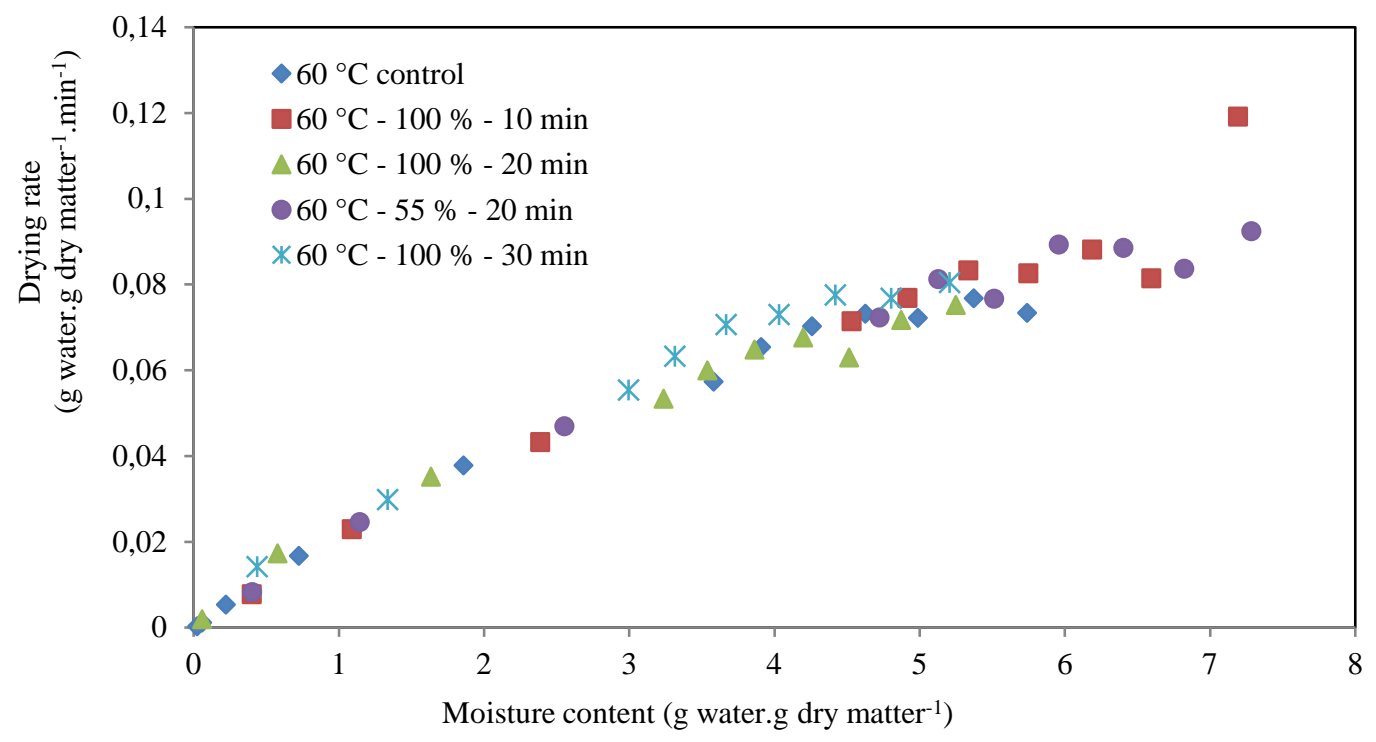

Figure 1. Drying curves of apple slices.

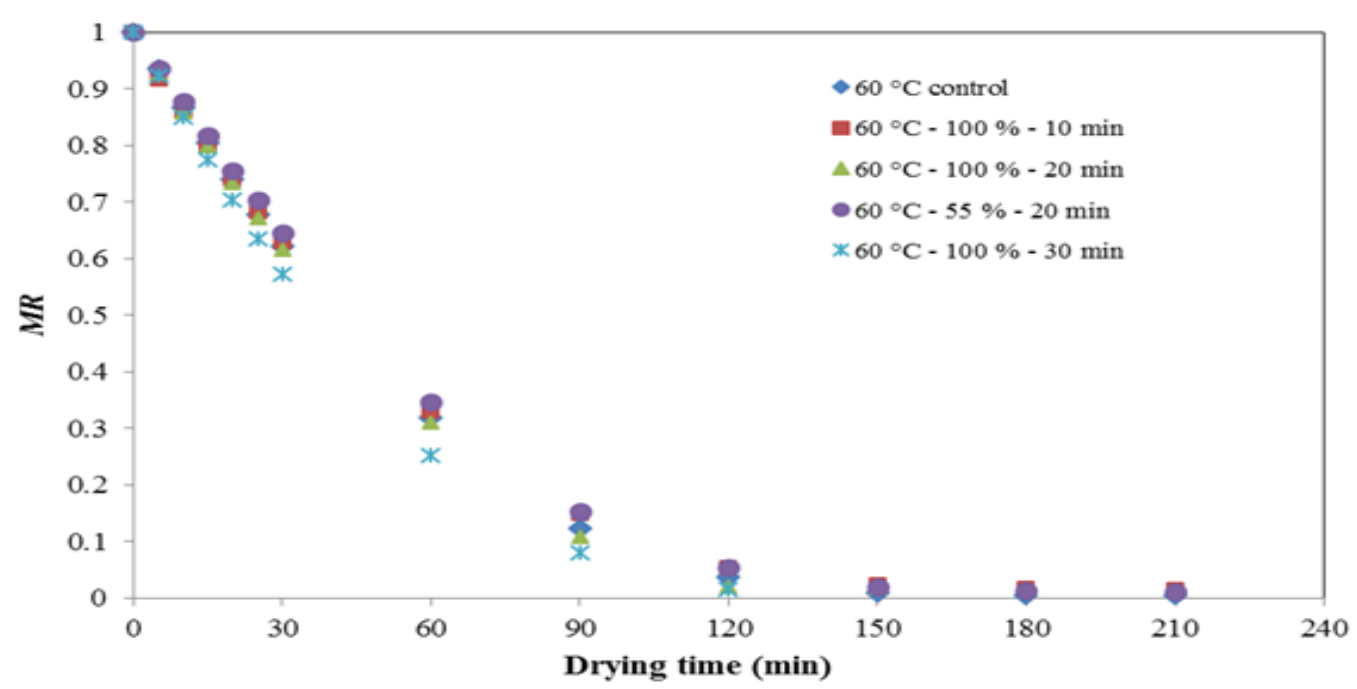

Figure 2. Drying kinetics of apple slices.

\subsection{Modeling of drying kinetics}

The $M R$ values of the apple slices were fitted to five different mathematical drying models and model constants and statistical comparison parameters for apple drying are given in Table 4. Page and Modified Page models were found to be the best fitted models for representing the drying kinetics of apple by providing higher $\mathrm{R}^{2}$ and lower $\chi^{2}$ and RMSE values for all conditions. 
Table 4. Model coefficients and statistical comparison parameters for apple drying

\begin{tabular}{|c|c|c|c|c|c|c|c|}
\hline $\begin{array}{l}\text { Sample } \\
\text { Code }\end{array}$ & $\begin{array}{l}\text { Model } \\
\text { No }\end{array}$ & & Model Coefficients & & $\mathrm{R}^{2}$ & RMSE & $\chi^{2}$ \\
\hline \multirow{5}{*}{$60^{\circ} \mathrm{C}$} & 1 & $\mathrm{k}=0.0268$ & & & 0.9780 & 0.0278 & 0.0108 \\
\hline & 2 & $\mathrm{a}=1.2418$ & $\mathrm{k}=0.0284$ & & 0.9838 & 0.0252 & 0.0097 \\
\hline & 3 & $\mathrm{k}=0.0079$ & $\mathrm{n}=1.2384$ & & 0.9958 & 0.0046 & 0.0003 \\
\hline & 4 & $\mathrm{k}=0.0200$ & $\mathrm{n}=1.2384$ & & 0.9958 & 0.0046 & 0.0003 \\
\hline & 5 & $\mathrm{a}=1.5938$ & $\mathrm{k}=0.0373$ & $c=0.0049$ & 0.9570 & 0.0604 & 0.0617 \\
\hline \multirow{5}{*}{$\begin{array}{c}60{ }^{\circ} \mathrm{C}- \\
100 \%- \\
10 \mathrm{~min}\end{array}$} & 1 & $\mathrm{k}=0.0229$ & & & 0.9857 & 0.0190 & 0.0051 \\
\hline & 2 & $\mathrm{a}=1.1515$ & $\mathrm{k}=0.0241$ & & 0.9906 & 0.0169 & 0.0044 \\
\hline & 3 & $\mathrm{k}=0.0115$ & $\mathrm{n}=1.1237$ & & 0.9926 & 0.0053 & 0.0004 \\
\hline & 4 & $\mathrm{k}=0.0188$ & $\mathrm{n}=1.1237$ & & 0.9926 & 0.0053 & 0.0004 \\
\hline & 5 & $\mathrm{a}=1.4965$ & $\mathrm{k}=0.0351$ & $\mathrm{c}=0.0167$ & 0.9580 & 0.0532 & 0.0477 \\
\hline \multirow{5}{*}{$\begin{array}{c}60{ }^{\circ} \mathrm{C}- \\
100 \%- \\
20 \mathrm{~min}\end{array}$} & 1 & $\mathrm{k}=0.0272$ & & & $0 . .9570$ & 0.0322 & 0.0125 \\
\hline & 2 & $\mathrm{a}=1.2572$ & $\mathrm{k}=0.0296$ & & 0.9696 & 0.0319 & 0.0136 \\
\hline & 3 & $\mathrm{k}=0.0114$ & $\mathrm{n}=1.2297$ & & 0.9908 & 0.0243 & 0.0080 \\
\hline & 4 & $\mathrm{k}=0.0207$ & $\mathrm{n}=1.2297$ & & 0.9908 & 0.0243 & 0.0080 \\
\hline & 5 & $\mathrm{a}=1.1360$ & $\mathrm{k}=0.0258$ & $\mathrm{c}=0.0175$ & 0.9708 & 0.0201 & 0.0061 \\
\hline \multirow{5}{*}{$\begin{array}{l}60{ }^{\circ} \mathrm{C}- \\
55 \%- \\
20 \mathrm{~min}\end{array}$} & 1 & $\mathrm{k}=0.0236$ & & & 0.9808 & 0.0242 & 0.0083 \\
\hline & 2 & $\mathrm{a}=1.2176$ & $\mathrm{k}=0.0253$ & & 0.9890 & 0.0228 & 0.0080 \\
\hline & 3 & $\mathrm{k}=0.0081$ & $\mathrm{n}=1.2024$ & & 0.9955 & 0.0043 & 0.0003 \\
\hline & 4 & $\mathrm{k}=0.0183$ & $\mathrm{n}=1.2024$ & & 0.9955 & 0.0043 & 0.0003 \\
\hline & 5 & $\mathrm{a}=1.1470$ & $\mathrm{k}=0.0331$ & $\mathrm{C}=0.0116$ & 0.9649 & 0.0491 & 0.0407 \\
\hline \multirow{5}{*}{$\begin{array}{l}60{ }^{\circ} \mathrm{C}- \\
100 \%- \\
30 \mathrm{~min}\end{array}$} & 1 & $\mathrm{k}=0.0300$ & & & 0.9664 & 0.0348 & 0.0134 \\
\hline & 2 & $\mathrm{a}=1,3010$ & $\mathrm{k}=0.0335$ & & 0.9674 & 0.0389 & 0.0189 \\
\hline & 3 & $\mathrm{k}=0.0092$ & $\mathrm{n}=1.2397$ & & 0.9928 & 0.0061 & 0.0005 \\
\hline & 4 & $\mathrm{k}=0.0228$ & $\mathrm{n}=1.2397$ & & 0.9928 & 0.0061 & 0.0005 \\
\hline & 5 & $\mathrm{a}=1.1677$ & $\mathrm{k}=0.0296$ & $\mathrm{c}=0.1516$ & 0.9739 & 0.0530 & 0.0402 \\
\hline
\end{tabular}

\subsection{Shrinkage}

The shrinkage ratio of the ultrasound pretreated samples reduced gradually as the pretreatment time and amplitude increased (Table 5).

Table 5. Shrinkage ratios of apple slices

\begin{tabular}{cc}
\hline Sample code & Shrinkage Ratio*(\%) \\
\hline $60{ }^{\circ} \mathrm{C}$ control & $88.00 \pm 0.44$ \\
$60^{\circ} \mathrm{C}-100 \%-10 \mathrm{~min}$ & $88.85 \pm 1.90$ \\
$60^{\circ} \mathrm{C}-100 \%-20 \mathrm{~min}$ & $85.33 \pm 0.24$ \\
$60{ }^{\circ} \mathrm{C}-55 \%-20 \mathrm{~min}$ & $87.76 \pm 0.22$ \\
$60^{\circ} \mathrm{C}-100 \%-30 \mathrm{~min}$ & $85.80 \pm 1.77$ \\
\hline
\end{tabular}

* Values are given as \pm standard deviation $\mathrm{n}=4$

\subsection{Rehydration kinetics}

Rehydration curves of dried apple slices, model coefficients and statistical parameters of Peleg model are given in Figure 3 and Table 6, respectively. The Peleg model had high $R^{2}$ and low $\chi^{2}$ and RMSE values which were represented empirical data successfully. 


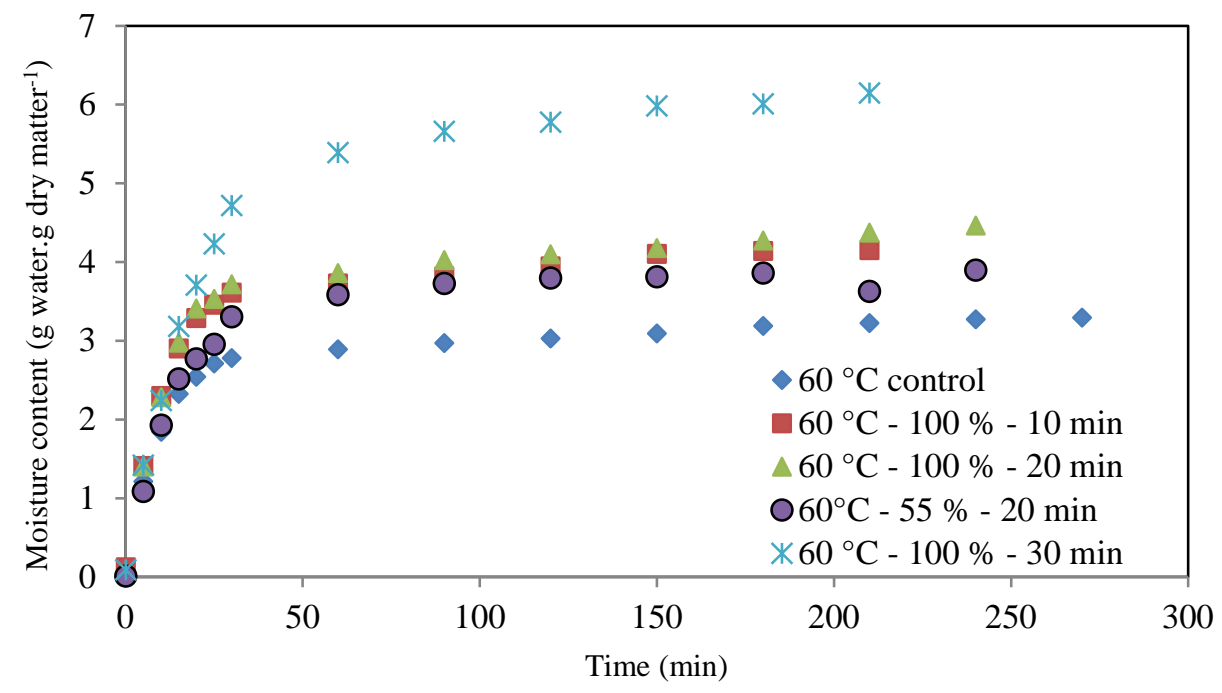

Figure 3. Rehydration curves of dried apple slices.

Table 6. Peleg model coefficients and statistical parameters for rehydration curves of dried apple slices

\begin{tabular}{lccccc}
\hline Sample code & $k_{1}$ & $k_{2}$ & $\mathrm{R}^{2}$ & RMSE & $\chi^{2}$ \\
\hline $60^{\circ} \mathrm{C}$ control & 0.0421 & 0.2992 & 0.9992 & 0.0289 & 0.0136 \\
$60^{\circ} \mathrm{C}-100 \%-10 \mathrm{~min}$ & 0.0337 & 0.2392 & 0.9992 & 0.0423 & 0.0266 \\
$60^{\circ} \mathrm{C}-100 \%-20 \mathrm{~min}$ & 0.0357 & 0.2229 & 0.9989 & 0.0452 & 0.0313 \\
$60^{\circ} \mathrm{C}-55 \%-20 \mathrm{~min}$ & 0.0363 & 0.2520 & 0.9974 & 0.0428 & 0.0282 \\
$60^{\circ} \mathrm{C}-100 \%-30 \mathrm{~min}$ & 0.0418 & 0.1535 & 0.9989 & 0.0525 & 0.0397 \\
\hline
\end{tabular}

\subsection{Rehydration ratio and water holding capacity}

The rehydration ratio increased with the increase in ultrasound pretreatment time and amplitude (Figure 4).

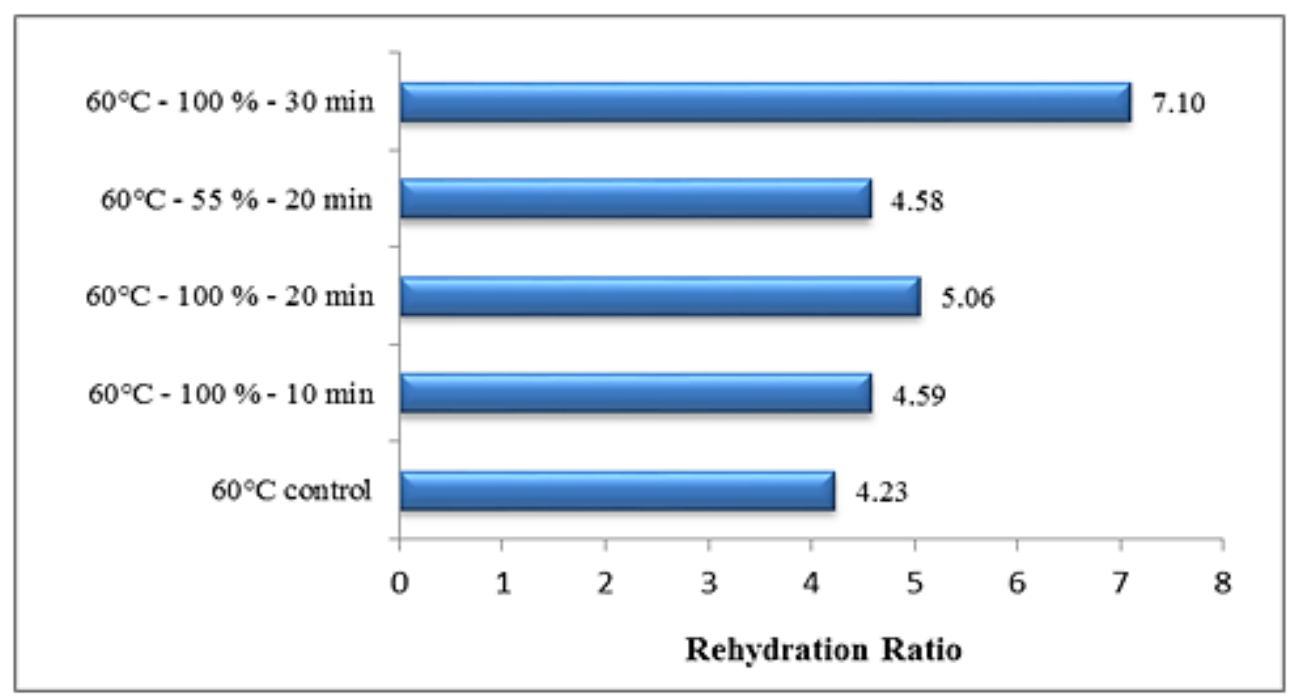

Figure 4. Rehydration ratio of apple slices. 
As can be seen in Figure 5 water holding capacity values increased with ultrasound pretreatment. With 10 min pretreatment at $100 \%$ amplitude ultrasound highest water holding capacity value was seen which is 3.83 times of the control sample.

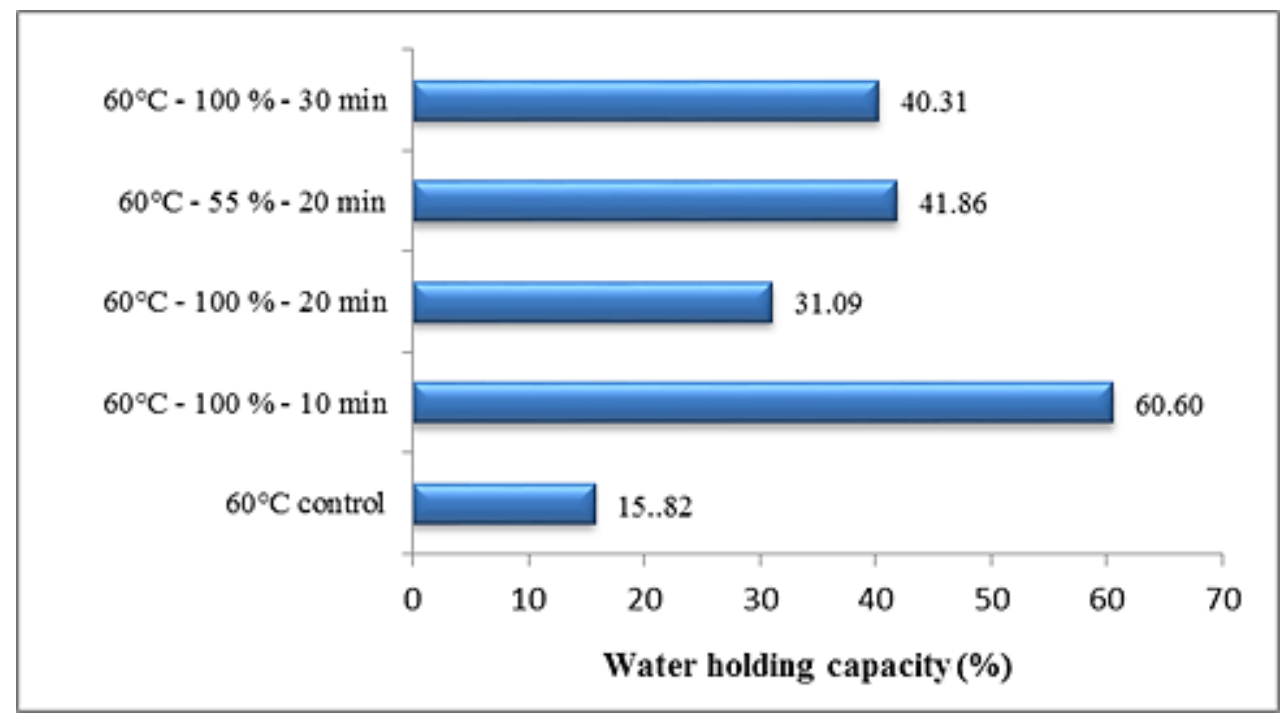

Figure 5. Water holding capacity of apple slices.

\subsection{Microstructural changes}

SEM micrographs of the untreated sample and the ultrasonically pretreated samples at 55 and $100 \%$ amplitudes for 20 min which were dried at $60{ }^{\circ} \mathrm{C}$ are given in Figure 6. Ultrasound pretreatment applied at different conditions caused differences in microstructure of the dried apple slices. The apple slices dried without pretreatment have more organized cell structures in comparison with pretreated samples. Disruption of cell walls and cell deformation occurred in apple tissues in consequence of acoustic cavitation which can be seen clearly in Figure 6b-c. 

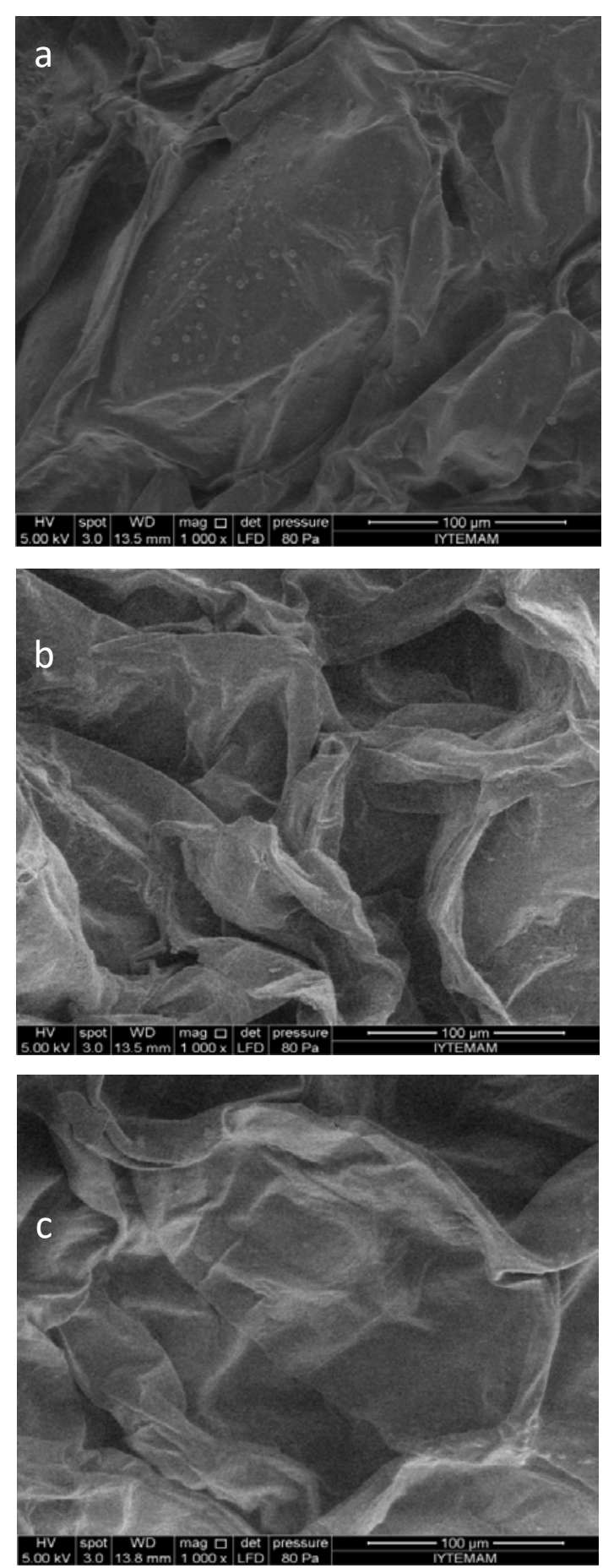

Figure 6. SEM micrographs of apple slices dried at $60^{\circ} \mathrm{C}$ : (a) Control (b) 20 min sonicated with $55 \%$ amplitude (c) 20 min sonicated with $100 \%$ amplitude.

\section{Discussion and Conclusion}

Rise in temperature of surrounding water during ultrasound pretreatment (Table 2) is due to the fact that the magnitude of acoustic energy transferred into the medium (surrounding water and apple slices) increases with increasing pretreatment time and ultrasound amplitude. Similar temperature rises based upon ultrasound energy were reported in the literature for mushroom, Brussel sprout and cauliflower (Jambrak et al., 2007).

Associated with ultrasound pretreatment, mass loss in the apple slices occurred as a result of soluble solid loss from the samples due to concentration gradient caused by the sugar content of the samples (Table 2). Ultrasonically pretreated pineapple (Fernandes et al., 2009) soluble solid loss also thought to be based on sugar content of fruit. 
As seen in the drying curves of ultrasonically pretreated apples, only the falling rate drying period was observed in all of the samples (Figure 1). Therefore, diffusion is the major physical mechanism of mass transfer in the apple samples. The same result was reported in hot air drying of Granny Smith apple (Andres et al, 2004) and ultrasound assisted convective drying of orange peel (Mello et al., 2020). Contreras et al. (2008) indicated that the Page and Modified Page models were represented the drying kinetics of apple products better than the other models like our study. Also, Page model successfully described the drying kinetics of ultrasonically pretreated pumpkin (Rojas et al., 2020), raspberry fruit (Szadzińska et al., 2019) and banana (Azoubel et al., 2010).

Shrinkage of food materials was an undesirable result of drying for consumer because of the changes in shape and loss of volume (Senadeera et al., 2020). For this study ultrasound pretreatment reducing effect on shrinkage ratio can be considered as a positive effect on dried product quality. Similar results were reported for hot air drying of Mirabelle plum (Dehghannya et al., 2016) and freeze drying of quince slices (Yildiz and İzli, 2019). The falling tendency in shrinkage values with ultrasound application might be due to microstructure damages which improve water diffusivity in apple tissue (Rodriguez et al., 2014). The relation between shrinkage and microstructural changes depending on ultrasound applications were also discussed for orange peel (Garcia-Perez et al., 2012).

Rehydration is a quality characteristic of dried foods and agricultural products that aims to recover the properties of raw materials which give information about the damage caused on the material due to drying and pretreatment methods (Cunningham et al., 2008). As a result of the structural deformation occurred in ultrasound pretreatment, increasing the pretreatment time and ultrasound amplitude accelerated the water gain (Figure 3). Wang et al. (2019) also reported that rehydration kinetics of kiwifruit was closely associated with microstructural changes that occurred after ultrasound pretreatment.

Rehydration kinetics of ultrasonically pretreated dried apples (cv. Idared) (Nowacka et al., 2012) and carrots (Ricce et al., 2016) were also well described by Peleg model with $R^{2}$ values above 0.99. Peleg model constant $k_{1}$ and $k_{2}$ which related to mass transfer rate and final equilibrium moisture content, affected by pretreatment and drying conditions. The lower value of $k_{1}$ means faster moisture gain. In comparison to other rehydrated apple samples, 10 min sonicated sample with $100 \%$ amplitude ultrasound had the lowest $k_{1}$ value which indicates the highest rehydration rate. $k_{2}$ changed oppositely with the equilibrium moisture content. So, the 30 min sonicated sample with $100 \%$ amplitude ultrasound had the highest equilibrium moisture content. The value of $k_{2}$ was influenced by process temperature and structural changes in rehydrated material (Deng and Zhao, 2008). In this rehydration process, differences in the values of $k_{2}$ can only be due to changes in chemical and physical structures of the apple slices during the ultrasound pretreatment just because of the constant rehydration temperature $\left(60^{\circ} \mathrm{C}\right)$.

Higher rehydration ratio with increasing ultrasound pretreatment time and amplitude can be explained by the increases in pore formation which was caused by cavitation (Figure 4). Rehydration capacity of apple (Mothibe et al., 2014) and sea cucumber (Duan et al., 2008) were improved significantly by ultrasound pretreatment. Similarly, during the ageing of beef; sonicated samples reached higher water holding capacity values (Stadnik et al., 2008).

Researchers reported that the cavitation generated by the ultrasonic energy creates microscopic channels and facilitates the diffusion of water for carrot (Chen et al., 2016) and purple sweet potato (Liu et al., 2017). This situation improves the mass transfer by generating alternative diffusion pathways which resulted in lower drying time and shrinkage (Dehghannya et al., 2016). Increasing the ultrasound amplitude flattened the cells and collapsed the apple tissues. Similar tissue changes based on ultrasound applications were also found in previous studies for Fuji apples (Deng and Zhao, 2008) and pineapple (Fernandes et al., 2009).

In conclusion, ultrasound application affects water transport in food tissue so the drying rate increases, the drying time and shrinkage decreases. However, there is a need for further studies for the optimization of ultrasound application conditions in order to produce different products at higher quality and nutrient values at shorter drying times.

\section{Acknowledgements}

The authors gratefully acknowledge Pamukkale University Scientifc Researches Project Unit (Project No: PAUBAP 2012FBE060) for fnancial support. 


\section{References}

Andres, A., Bilbao, C., \& Fito, P. (2014). Drying kinetics of apple cylinders under combined hot airmicrowave dehydration. Journal of Food Engineering, 63(1), 71-78.

Aras, S., \& Eşitken, A. (2019). Responses of apple plants to salinity stress. Yüzüncü Yıl Üniversitesi Tarım Bilimleri Dergisi, 29(2), 253-257.

Azoubel, P.M., Baima, M.D.A.M., da Rocha Amorim, M., \& Oliveira, S.S.B. (2010). Effect of ultrasound on banana cv Pacovan drying kinetics. Journal of Food Engineering, 97(2), 194-198.

Banaszak, J., \& Pawłowski, A. (2018). Influence of ultrasound assist during hot air drying on properties of dried apple crisps. Chemical and Process Engineering, 39(3), 263-270.

Chen, Z. G., Guo, X. Y., \& Wu, T. (2016). A novel dehydration technique for carrot slices implementing ultrasound and vacuum drying methods. Ultrasonics sonochemistry, 30, 28-34.

Contreras, C., Martín-Esparza, M. E., Chiralt, A., \& Martínez-Navarrete, N. (2008). Influence of microwave application on convective drying: Effects on drying kinetics, and optical and mechanical properties of apple and strawberry. Journal of Food Engineering, 88(1), 55-64.

Cruz, A. C., Guiné, R. P., \& Gonçalves, J. C. (2015). Drying kinetics and product quality for convective drying of apples (cvs. Golden Delicious and Granny Smith). International Journal of Fruit Science, 15(1), 54-78.

Cunningham, S. E., Mcminn, W. A. M., Magee, T.R.A., \& Richardson, P. S. (2008). Experimental study of rehydration kinetics of potato cylinders. Food and bioproducts processing, 86(1), 15-24.

Demiray, E., \& Tulek, Y. (2014). Drying characteristics of garlic (Allium sativum L) slices in a convective hot air dryer. Heat and Mass Transfer, 50(6), 779-786.

Deng, Y., \& Zhao, Y. (2008). Effect of pulsed vacuum and ultrasound osmopre-treatments on glass transition temperature, texture, microstructure and calcium penetration of dried apples (Fuji). LWT-Food Science and Technology, 41(9), 1575-1585.

Dehghannya, J., Gorbani, R., \& Ghanbarzadeh, B. (2016). Shrinkage of Mirabelle plum during hot air drying as influenced by ultrasound-assisted osmotic dehydration. International journal of food properties, 19(5), 1093-1103.

Duan, X., Zhang, M., Li, X., \& Mujumdar, A. S. (2008). Ultrasonically enhanced osmotic pretreatment of sea cucumber prior to microwave freeze drying. Drying Technology, 26(4), 420-426.

Fernandes, F. A., Braga, T. R., Silva, E. O., \& Rodrigues, S. (2019). Use of ultrasound for dehydration of mangoes (Mangifera indica L.): kinetic modeling of ultrasound-assisted osmotic dehydration and convective air-drying. Journal of food science and technology, 56(4), 1793-1800.

Fernandes, F. A., Gallão, M. I., \& Rodrigues, S. (2009). Effect of osmosis and ultrasound on pineapple cell tissue structure during dehydration. Journal of Food Engineering, 90(2), 186-190.

Garcia-Perez, J. V., Ortuño, C., Puig, A., Carcel, J. A., \& Perez-Munuera, I. (2012). Enhancement of water transport and microstructural changes induced by high-intensity ultrasound application on orange peel drying. Food and Bioprocess Technology, 5(6), 2256-2265.

Garcia-Perez, J. V., Cárcel, J. A., Benedito, J., \& Mulet, A. (2007). Power ultrasound mass transfer enhancement in food drying. Food and Bioproducts Processing, 85(3), 247-254.

Jambrak, A. R., Mason, T. J., Paniwnyk, L., \& Lelas, V. (2007). Accelerated drying of button mushrooms, Brussels sprouts and cauliflower by applying power ultrasound and its rehydration properties. Journal of Food Engineering, 81(1), 88-97.

Knorr, D., Zenker, M., Heinz, V., \& Lee, D. U. (2004). Applications and potential of ultrasonics in food processing. Trends in Food Science \& Technology, 15(5), 261-266.

Liu, Y., Sun, Y., Yu, H., Yin, Y., Li, X., \& Duan, X. (2017). Hot air drying of purple-fleshed sweet potato with contact ultrasound assistance. Drying Technology, 35(5), 564-576.

Lv, W., Lv, H., Jin, X., Cui, Z., \& Su, D. (2019). Effects of ultrasound-assisted methods on the drying processes and quality of apple slices in microwave drying. Drying Technology, 1-11.

Mello, R. E., Fontana, A., Mulet, A., Correa, J. L. G., \& Cárcel, J. A. (2020). Ultrasound-assisted drying of orange peel in atmospheric freeze-dryer and convective dryer operated at moderate temperature. Drying Technology, 38(1-2), 259-267.

Mierzwa, D., \& Kowalski, S. J. (2016). Ultrasound-assisted osmotic dehydration and convective drying of apples: Process kinetics and quality issues. Chemical and Process Engineering, 37(3), 383391. 
Moreno, C., Brines, C., Mulet, A., Rosselló, C., \& Cárcel, J. A. (2017). Antioxidant potential of atmospheric freeze-dried apples as affected by ultrasound application and sample surface. Drying Technology, 35(8), 957-968.

Mothibe, K. J., Zhang, M., Mujumdar, A. S., Wang, Y. C., \& Cheng, X. (2014). Effects of ultrasound and microwave pretreatments of apple before spouted bed drying on rate of dehydration and physical properties. Drying Technology, 32(15), 1848-1856.

Nowacka, M., Wiktor, A., Śledź, M., Jurek, N., \& Witrowa-Rajchert, D. (2012). Drying of ultrasound pretreated apple and its selected physical properties. Journal of Food Engineering, 113(3), 427433.

Rastogi, N. K. (2011). Opportunities and challenges in application of ultrasound in food processing. Critical reviews in food science and nutrition, 51(8), 705-722.

Ren, Z., \& Bai, Y. (2018, August). Ultrasound Pretreatment of Apple Slice Prior to Vacuum Freeze Drying. In 2nd International Conference on Material Science, Energy and Environmental Engineering (MSEEE 2018). Atlantis Press.

Ricce, C., Rojas, M. L., Miano, A. C., Siche, R., \& Augusto, P. E. D. (2016). Ultrasound pre-treatment enhances the carrot drying and rehydration. Food Research International, 89, 701-708.

Rojas, M. L., Silveira, I., \& Augusto, P. E. D. (2020). Ultrasound and ethanol pre-treatments to improve convective drying: Drying, rehydration and carotenoid content of pumpkin. Food and Bioproducts Processing, 119, 20-30.

Sabarez, H. T., Keuhbauch, S., \& Knoerzer, K. (2018, September). Ultrasound assisted low temperature drying of food materials. In IDS 2018. 21st International Drying Symposium Proceedings (pp. 1245-1250). Editorial Universitat Politècnica de València.

Sacilik, K., \& Elicin, A. K. (2006). The thin layer drying characteristics of organic apple slices. Journal of Food Engineering, 73(3), 281-289.

Senadeera, W., Adiletta, G., Önal, B., Di Matteo, M., \& Russo, P. (2020). Influence of different hot air drying temperatures on drying kinetics, shrinkage, and colour of persimmon slices. Foods, 9(1), 101.

Stadnik, J., Dolatowski, Z. J., \& Baranowska, H. M. (2008). Effect of ultrasound treatment on water holding properties and microstructure of beef (m. semimembranosus) during ageing. LWT-Food Science and Technology, 41(10), 2151-2158.

Szadzińska, J., Łechtańska, J., Pashminehazar, R., Kharaghani, A., \& Tsotsas, E. (2019). Microwaveand ultrasound-assisted convective drying of raspberries: Drying kinetics and microstructural changes. Drying Technology, 37(1), 1-12.

Turgut, D. Y., \& Topuz, A. (2020) Depolama Süresinin Farklı Kurutma Yöntemleri ile Kurutulmuş Kamkat Dilimlerinin Bazı Kalite Özelliklerine Etkisi. Yüzüncü Yıl Üniversitesi Tarım Bilimleri Dergisi, 30(1), 44-56.

Tüfekçi, S., \& Özkal, S. G. (2017). Enhancement of drying and rehydration characteristics of okra by ultrasound pre-treatment application. Heat and Mass Transfer, 53(7), 2279-2286.

Vega-Gálvez, A., Di Scala, K., Rodríguez, K., Lemus-Mondaca, R., Miranda, M., López, J., \& PerezWon, M. (2009). Effect of air-drying temperature on physico-chemical properties, antioxidant capacity, colour and total phenolic content of red pepper (Capsicum annuum, L. var. Hungarian). Food Chemistry, 117(4), 647-653.

Wang, J., Xiao, H. W., Ye, J. H., Wang, J., \& Raghavan, V. (2019). Ultrasound pretreatment to enhance drying kinetics of Kiwifruit (Actinidia deliciosa) slices: Pros and cons. Food and bioprocess technology, 12(5), 865-876.

Wiktor, A., \& Witrowa-Rajchert, D. (2020). Drying kinetics and quality of carrots subjected to microwave-assisted drying preceded by combined pulsed electric field and ultrasound treatment. Drying Technology, 38(1-2), 176-188.

Yildiz, G., \& İzli, G. (2019). The effect of ultrasound pretreatment on quality attributes of freeze-dried quince slices: Physical properties and bioactive compounds. Journal of Food Process Engineering, 42(5), e13223.

Zhang, L., Liao, L., Qiao, Y., Wang, C., Shi, D., An, K., \& Hu, J. (2020). Effects of ultrahigh pressure and ultrasound pretreatments on properties of strawberry chips prepared by vacuum-freeze drying. Food chemistry, 303, 125386. 